\title{
In the Grip of Sacred History
}

\section{Citation}

Smail, Daniel. 2005. In the grip of sacred history. American Historical Review 110, no. 5: 1336-1361.

\section{Published Version}

http://dx.doi.org/10.1086/ahr.110.5.1337

\section{Permanent link}

http://nrs.harvard.edu/urn-3:HUL.InstRepos:3207678

\section{Terms of Use}

This article was downloaded from Harvard University's DASH repository, and is made available under the terms and conditions applicable to Other Posted Material, as set forth at http:// nrs.harvard.edu/urn-3:HUL.InstRepos:dash.current.terms-of-use\#LAA

\section{Share Your Story}

The Harvard community has made this article openly available.

Please share how this access benefits you. Submit a story.

Accessibility 


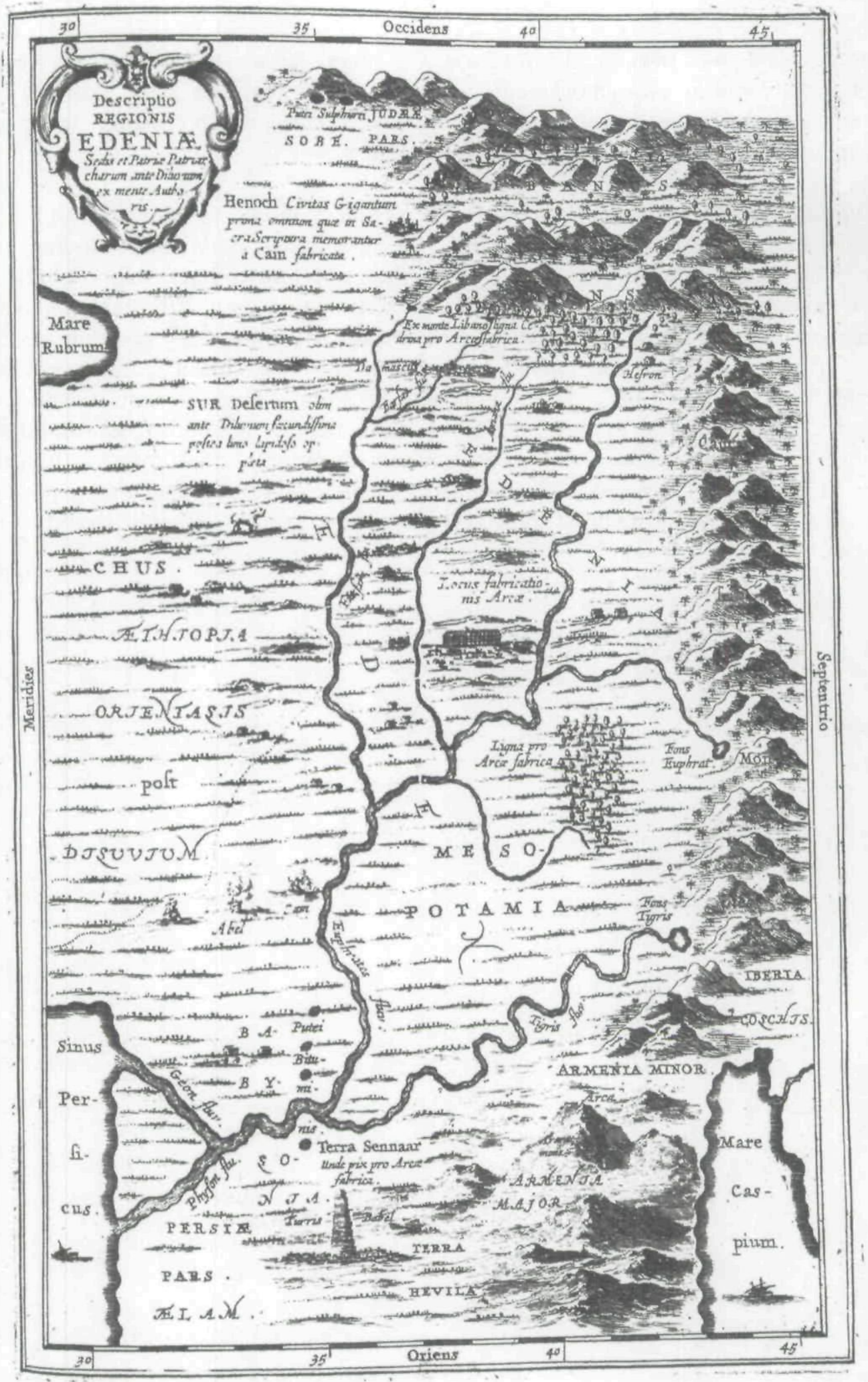

FronTISPIECE: Noah's Ark under construction in Edenia. From Athanasius Kircher, Arca Noë. Reproduced courtesy of Fordham University Library Special Collections. 


\section{DAN SMAIL}

ON THE OTHER SIDE OF EDEN lies a vast stretch of human history punctuated by compelling stories and events. ${ }^{1}$ The ancestral Eve, the Out-of-Africa hypothesis, the Great Leap Forward, the settling of the Americas, the debates that rage around megafaunal extinction and the demise of the Neanderthals: all these and more have gripped the imaginations of academics and amateurs alike. If humanity is the proper subject of history, then surely the Paleolithic is part of our history. Yet despite enormous strides in the field of paleoanthropology over the last several decades, the deep past of humanity still plays a marginal role in the grand historical narrative that is taught in secondary schools and colleges in the United States. Most textbooks used in Western Civilization courses include very little on the Neolithic era, and even less on the Paleolithic. Some books in world history extend human history back to the outset of the agricultural revolutions, breaching the date of six thousand years ago that dominates some Western Civilization textbooks. Yet even world history surveys currently do not deal significantly with the Paleolithic. ${ }^{2}$

If history is biography -if the study of history, to be satisfying, requires us to make contact with the thoughts and psyches of people with names-then there is little point in advocating a deep history of humankind. But if history is also the study of the structures and patterns that shape the human experience, if acts such as handling a flint arrowhead or tracing one's mitochondrial family tree back to a small African valley can fulfill our desire for wonder, then the exclusion of humanity's deep history cannot be so easily explained. Puzzling over this exclusion, the archaeologist Glyn

My thanks to Doris Goldstein, Lynn Hunt, the members of the Fordham history faculty seminar, and the undergraduates who have taken my course "A Natural History," especially Edward Djordjevic and Maria Dembrowsky, for reading and commenting on preliminary versions of these arguments. I would also like to thank David Nirenberg, Gabrielle Spiegel, and the high school teachers involved in the Big History project at Chatham High School (N.Y.), especially Mike Wallace, for sharing ideas.

${ }^{1}$ I borrow the expression from Hugh Brody, The Other Side of Eden: Hunters, Farmers, and the Shaping of the World (New York, 2000).

2 The first edition of William H. McNeill's The Rise of the West: A History of the Human Community (Chicago, 1963), especially important because of its subsequent influence, devoted eight pages to the Paleolithic in a book of some eight hundred pages. William J. Duiker and Jackson J. Spielvogel cover prehistory in two pages of their Essential World History: Comprehensive Volume, 3rd ed. (Belmont, Calif., 2001). A more trade-oriented title, J. R. McNeill and William McNeill's The Human Web: A Bird's-Eye View of World History (New York, 2003), covers the Paleolithic in sixteen pages, although their "web" model offers an intriguing device for joining the Paleolithic to the later periods. Michael Cook's general history, A Brief History of the Human Race (New York, 2003), suggests that the Paleolithic does not count as history in part because there are no documents from the period that allow us to "study past humans on the basis of what they had to say for themselves" (5). An important exception to this neglect of early human history can be found in David Christian, Maps of Time: An Introduction to Big History (Berkeley, Calif., 2004). 
Daniel once wrote: "Why do historians in a general way pay so little attention to this fourth division of the study of the human past; while recognizing ancient history do they not give more recognition to prehistory? ... Historians are taking a long time to integrate prehistory into their general view of man." 3 That was in 1962 . Since then, the call for interdisciplinarity has encouraged historians to approach the past through tools provided by other disciplines. However, this interdisciplinarity has not yet been extended to the fields that constitute the realm of paleoanthropology. Deep history, for all intents and purposes, is still prehistory-a term, as Mott Greene has noted, that modern historians have been reluctant to let drop. "To abandon prehistory," he says, "would be to postulate continuity between the biological descent of hominids and the 'ascent of civilization' of the abstract 'mankind' of humanistic historical writing. Prehistory is a buffer zone." ${ }^{4}$

The purpose of this article is to explore some of the historiographical reasons for the continuing exclusion of deep history. I do not intend to offer suggestions for how we can go about actually emplotting the Paleolithic in textbooks, general histories, and lectures. That is the subject for future work. ${ }^{5}$ Instead, what I will argue here is that the narrative of Western Civilization as it is currently understood by historians in the United States has not fully escaped the chronological and geographical grip of sacred history. Sacred history, as promulgated by early modern European historians and their predecessors in the Judeo-Christian tradition, was a view of history that located the origins of man in the Garden of Eden in 4004 B.C. In the eighteenth century, the chronology proper to history shrank significantly, as the new fad for catastrophism brought historical attention to bear on the Universal Deluge. Since human societies were rebuilt from scratch after the Deluge-so the thinking went-it was the Deluge that marked mankind's true beginning. And in the philosophy of the Neapolitan historian Giambattista Vico (1668-1744), the Deluge made all prior history unknowable anyway, because it destroyed all traces from which we could write such a history. As an event that set the civilizational clock back to zero, the Deluge marked an epistemological break between humanity's origin and the present stream of history. Although the flood itself has long since receded in historical consciousness, the sense of rupture remains.

In the middle of the nineteenth century, with the discovery of geological time, Western Europe's chronological certainties came crashing down. Stephen Jay Gould has called the discovery of deep time a cosmological revolution of Galilean proportions, and the new chronology came to shape all the historical sciences. ${ }^{6}$ But how did historians respond to the long chronology? Like all educated people, the general historians of the later nineteenth century were aware of deep time. A few continued to affirm the truths of Judeo-Christian chronology in the face of the mounting evidence. Motivated by the professionalizing wave of the last decades of the nineteenth century, however, most historians in the United States were comfortable letting go

${ }^{3}$ Glyn E. Daniel, The Idea of Prehistory (London, 1962), 134.

${ }^{4}$ Mott T. Greene, Natural Knowledge in Preclassical Antiquity (Baltimore, Md., 1992), 3.

5 But see David Christian, "The Case for Big History," Journal of World History 2 (1991): 223-238;

Fred Spier, The Structure of Big History: From the Big Bang until Today (Amsterdam, 1996).

${ }^{6}$ Stephen Jay Gould, Time's Arrow, Time's Cycle: Myth and Metaphor in the Discovery of Geological Time (Cambridge, Mass., 1987), 1; see also Stephen Toulmin and June Goodfield, The Discovery of Time (New York, 1965). 
of the short chronology. Yet the historical narrative that emerged in the United States between the late nineteenth century and the 1940s did not fully abandon the narrow chronological space into which the diluvial paradigm had consigned secular history. Instead, the sacred was deftly translated into a secular key, as Sumeria and the invention of writing replaced the Garden of Eden as the point of origin for Western Civilization. Prehistory came to be an essential part of the story, but the era was cantilevered outside the narratival buttresses that sustain the edifice of Western Civilization. It was there only to illustrate what we are no longer.

Although the general histories published before World War II discarded the sacred, in other words, they nonetheless preserved the short chronology and the Mesopotamian geography of sacred history. The trend persisted in the postwar era. As the authors of The Columbia History of the World (1972) put it, "History begins in the Near East."7 Acknowledging the abyss of time, however, the authors of textbooks and general histories published between the 1860 s and 1930 s felt an obligation to justify their adherence to the short chronology. They noted the absence of written documents. They proposed the idea that history concerns nations, not rootless bands. They developed the myth of Paleolithic stasis, the idea of a timeless dystopia whose unchangingness was broken only, deus ex machina, by some ill-defined catalytic event. In these and other ways, they justified the absence of any narratival continuity between prehistory and history.

The continuing significance of these arguments derives from the fact that however toothless they have become, they continue to influence the ways in which we imagine history and frame curricula. What do we gain by exposing them? One might just as well ask why historians of women thought it necessary to explore the historiographical grip of patriarchy even as they undertook the task of writing a women's history. Historiographical revisions have to proceed both materially and historiographically. The big history proposed by David Christian and others cannot make headway unless we expose the chronogeographic grip of sacred history and reexamine the trends that have prevented deep history from taking its place in the curriculum of history.

In the pages that follow, I make no claim to completeness. Apart from Daniel Segal's important study of the use of social evolutionary theory in Western Civilization courses and Doris Goldstein's work on the Oxford School, very little work has been done on historians' reception of deep time. ${ }^{8}$ The project, moreover, is large, and I can claim only to have brushed the surface of the relevant sources. This is a prolegomenon. It hopes to inspire debate and suggest lines of research.

ALL HISTORIANS MUST GRAPPLE WITH THE QUESTION of where to begin the story. For historians of the particular, the problem of origins is not especially acute: choose some reasonably datable event, and have that mark the beginning of your particular history. General historians face a slightly different problem. General history, as de-

7 John A. Garraty and Peter Gay, eds., The Columbia History of the World (New York, 1972), 49.

8 Daniel A. Segal, " 'Western Civ' and the Staging of History in American Higher Education," AHR 105, no. 3 (June 2000): 770-805; Doris Goldstein, "Confronting Time: The Oxford School of History and the Non-Darwinian Revolution," Storia della Storiografia 45 (2004): 3-27. 
fined by Herbert Butterfield, is a rational account of man on earth that explains "how mankind had come from primitive conditions to its existing state."9 I use the term to embrace the universal histories of the ancient world and medieval Europe, the general world histories of the nineteenth and twentieth centuries, and the histories found in modern history textbooks, syllabuses, and lectures. Whatever their differences, all purport to begin at the beginning. But if one's object is the whole history of humanity, where, exactly, is the beginning?

Musing on the point of origins, the Greek poet Hesiod invented a Golden Age and proposed decay as the dominant historical trajectory. For ancient and medieval historians writing in the Judeo-Christian tradition, the trajectory was similar, although sacred history and the story of Eden supplanted the Golden Age. Universal histories became less fashionable in early modern Europe, but the impulse to begin at the beginning did not wholly wane. Sir Walter Ralegh's History of the World in Five Books, first published in the early seventeenth century, began in Eden and worked its way down to the Roman period. Jacques Bénigne Bossuet's famed An Universal History (1681) also began the story with Genesis. ${ }^{10}$

The practice of writing mainstream professional histories rooted in Eden would persist well into the nineteenth century. But even in Ralegh's day, historians and commentators such as Jean Bodin (1529-1596) were trying to bring a progressive element into the writing of history. Influenced by the natural or conjectural histories of the ancient world that had identified the aboriginal state of humankind as primitive, Bodin denied the existence of a Golden Age and made much of the lawlessness and violence of the early phases of society. ${ }^{11}$ These ideas were shared by other sixteenth-century anthropologists, who proposed the idea of a progression from pastoral to agricultural society. ${ }^{12}$ The schemes subsequently developed by philosophers, economists, and ethnographers in the seventeenth and eighteenth centuries were also influenced by the growing number of reports concerning the savage peoples of the Caribbean, North America, Tierra del Fuego, and elsewhere. By the eighteenth century, there was a common understanding that humans had progressed through several economic stages-savagery, pastoralism, agriculture, and commerce were the usual suspects - and that each stage was associated with a particular set of political, social, legal, and intellectual institutions.

But how could the progressive fashion be squared with the chronological facts and the descending trajectory of sacred history? Peter Bowler has remarked that the idea that man acquired civilization in gradual stages required more time than was allowed by biblical chronology. ${ }^{13}$ Yet the authors of conjectural histories did not necessarily offend a biblical time frame. Writing in the eighteenth century, Condorcet and Adam Smith dodged the issue by refusing to assign any dates to their

${ }^{9}$ Herbert Butterfield, Man on His Past: The Study of the History of Historical Scholarship (Cambridge, 1955), 103.

${ }^{10}$ Sir Walter Ralegh, The History of the World in Five Books (London, 1687); Jacques Bénigne Bossuet, An Universal History: From the Beginning of the World to the Empire of Charlemagne, trans. James Elphinston, 13th ed. (Dublin, 1785).

${ }^{11}$ Jean Bodin, Method for the Easy Comprehension of History, trans. Beatrice Reynolds (New York, 1966), 298; see also Robert Nisbet, History of the Idea of Progress (New York, 1980).

${ }_{12}$ In general, see Margaret T. Hodgen, Early Anthropology in the Sixteenth and Seventeenth Centuries (Philadelphia, Pa., 1964),

${ }^{13}$ Peter J. Bowler, The Invention of Progress: The Victorians and the Past (Oxford, 1989), 76. 
armchair speculations. Others, notably the French physiocrat Turgot, were quite willing to squeeze the stages of progress into the short span of time made available by Holy Writ. ${ }^{14}$ Adam Ferguson similarly framed the history of mankind in the limited time period allowed for by sacred chronology. ${ }^{15}$ Few saw an essential contradiction with sacred history, because no one knew how long it took societies to evolve.

The chronological conundrums were easy to square. Sacred and conjectural histories, however, were profoundly incompatible in another way, for they disagreed on history's direction. Is it from Eden downward? Or from the primitive upward? Yet there was a solution to this problem. Embedded in the famous historical scheme promulgated by Turgot in A Philosophical Review of the Successive Advances of the Human Mind (1750) was a kind of biblical catastrophism, the idea that an event or events described in sacred history had wiped the slate clean and reset the clock of civilization to zero:

Holy Writ, after having enlightened us about the creation of the universe, the origin of man, and the birth of the first arts, before long puts before us a picture of the human race concentrated again in a single family as the result of a universal flood. Scarcely had it begun to make good its losses when the miraculous confusion of tongues forced men to separate from one another. The urgent need to procure subsistence for themselves in barren deserts, which provided nothing but wild beasts, obliged them to move apart from one another in all directions and hastened their diffusion through the whole world. Soon the original traditions were forgotten; and the nations, separated as they were by vast distances and still more by the diversity of languages, strangers to one another, were almost all plunged into the same barbarism in which we still see the Americans. ${ }^{16}$

This, the crucial compromise, allowed conjectural history and economic stage theory to be reconciled with sacred history. Sacred history provided historians with at least three catastrophes - the expulsion from the Garden of Eden, the Universal Deluge, and the destruction of the Tower of Babel-that could be said to have returned humankind to a primitive condition. The ascent of man, as predicted by theories of progress, could begin from any of the three points.

Of these, the Deluge easily loomed the largest. An event of monstrous significance, it has seldom failed to grip the European imagination. ${ }^{17}$ The Deluge was a prominent feature in the geological treatises of the seventeenth and eighteenth centuries and figures significantly in other writings. Its implications were not lost on historians and economists. In his On the Origin of Laws, Arts, and Sciences (1758), Antoine-Yves Goguet argued that the Deluge caused humans to forget the use of iron and other metals and return to the use of tools based on stone. ${ }^{18}$ Ferguson also made an allusion to the Deluge. ${ }^{19}$ And it was not just conjectural historians who played with the idea. Bossuet's great Universal History suggested how mankind was 42,65 .

14 Ronald L. Meek, ed. and trans., Turgot on Progress, Sociology and Economics (Cambridge, 1973),

${ }^{15}$ Adam Ferguson, An Essay on the History of Civil Society, ed. Fania Oz-Salzberger (Cambridge, 1995), 74.

${ }_{16}$ Meek, Turgot on Progress, 42.

17 See most recently Norman Cohn, Noah's Flood: The Genesis Story in Western Thought (New Haven, Conn., 1996).

18 See Donald K. Grayson, The Establishment of Human Antiquity (New York, 1983), 12-13, for similar arguments made by Goguet's contemporaries.

19 Ferguson, An Essay, 74. 
reduced to nearly nothing after the Deluge and then, by degrees, slowly emerged from ignorance, transforming woods and forests into fields, pastures, hamlets, and towns, and learning how to domesticate animals. ${ }^{20}$ This use of the Deluge as a resetting event in both sacred history and geology would persist into the nineteenth century. ${ }^{21}$

Conjectural historians, it is true, were not much interested in origins. Sacred historians such as Ralegh and Bossuet, in turn, wrote much about the Deluge but were correspondingly less interested in outlining the stages of postdiluvial progress. It was the Neapolitan historian Giambattista Vico who, in his New Science (1725), most persuasively reconciled the Deluge with the theory of human progress. ${ }^{22}$ Vico was not widely known in his own day, but his New Science was rediscovered in the early decades of the nineteenth century, and his reputation was resurrected to the point where he, with Leopold von Ranke, has often been called the father of modern history. His emphasis on the Deluge was the key element of a philosophy designed to orient history around the proper interpretation of myths and legends, thereby avoiding idle speculation and armchair philosophizing. A consequence of this approach was to exclude sacred history from the terrain of the secular historian, on the theory that no documents apart from the sacred writings carried by Noah had survived the flood. ${ }^{23}$

Vico was clearly attracted to the idea of progress. But whereas Bodin was disinterested in the Deluge, preferring instead to describe ante- and postdiluvial societies as identical in their primitiveness, Vico molded it into a powerful punctuating event. ${ }^{24}$ The singular importance of the Deluge in Vico's history is reflected in the chronological table printed in New Science, which begins in the year 1656 A.M. (anno mundi), the year of the Deluge. In a telling phrase, Vico actually describes his work as "a new natural history of the universal flood." 25 By the light of this natural history, the Deluge was seen as a catastrophic event that forced humans into the most primitive of conditions, far more abject than anything experienced in the preceding 1,656 years of sacred history. His enthusiasm reflected in his redundancy, Vico writes in many places of a period of brutish wandering during which the three tribes of men were scattered throughout the world's forests and copulated promiscuously with mothers and daughters, unmindful of kinship. Much that Vico wrote was compatible, and designed to be compatible, with the anthropology of his day.

Far more than Turgot, Vico's concept of historical chronology was thoroughly permeated by a philosophy of catastrophism. Catastrophism, the dominant paradigm in eighteenth-century geology, was not antithetical to conjectural history. Concerned

${ }^{20}$ Bossuet, Universal History, 8-10.

${ }^{21}$ For example, Sharon Turner, The History of the Anglo-Saxons from the Earliest Period to the Norman Conquest (1799-1805; repr., Philadelphia, Pa., 1841), 1: 27-28; David Ramsay, Universal History Americanised; or, An Historical View of the World, from the Earliest Records to the Year 1808 (Philadelphia, Pa., 1819), 9-22. See also Charles Coulston Gillespie, Genesis and Geology: A Study in the Relations of Scientific Thought, Natural Theology and Social Opinion in Great Britain, 1790-1850 (New York, 1951); George W. Stocking, Jr., Victorian Anthropology (New York, 1987), 33-34, 43.

${ }_{22}$ Giambattista Vico, New Science, 3rd ed., trans. David Marsh (London, 1999).

${ }^{23}$ A trend under way since the fifteenth or sixteenth centuries; see Ernst Breisach, Historiography: Ancient, Medieval and Modern, 2nd ed. (Chicago, 1994), 171-185.

${ }^{24}$ For the single bland reference to the flood in the pages where Bodin dismantles the myth of a Golden Age, see Method, 298.

25 Vico, New Science, 33, 143. 
with process, conjectural historians did not trouble themselves with origins. To make their schemes work, all they needed was a set of primitive or presocial conditions. They could make their peace with the idea that a catastrophe such as the Deluge had reset the clock to zero. In this view, history did not have to begin with human origins, where Eusebius, Otto of Freising, Ralegh, and other general historians had chosen to begin. Instead, the catastrophic paradigm authorized a history that began in the middle, on the heels of a catastrophe. The philosophy promoted so vividly by Vico, in other words, authorized the compression of historical time. This compression would persist long after the Deluge vanished from the historical imagination.

THE COMPRESSION OF HISTORICAL TIME made little practical difference as long as historical time itself was of short duration. Until the discovery and acceptance of deep time in the middle of the nineteenth century, human history as imagined in the Judeo-Christian tradition was coterminous with the history of the earth itself. ${ }^{26}$ It is true that Aristotle and others had proposed the idea of an eternal earth, and speculations on the age of the world greatly engaged ancient and medieval philosophers. Historians writing in the Judeo-Christian tradition could hardly resist the temptation to assign a date, and assiduously combed the book of Genesis for clues. Genesis, alas, speaks of generations, not dates, and historians were forced to count generations in the manner of previous Greek, Syrian, and Jewish historians. In the fourth century, Eusebius, bishop of Caesarea, had Adam created in the year 5198 B.C., and this was the date used by Jerome, Paulus Orosius, and many other Christian historians. In the seventeenth century, the busy recalculations of a number of scholars resulted in a diversity of dates, ranging from 3700 to 7000 B.C., although the date favored by James Ussher, 4004 B.C., soon emerged as the consensus. ${ }^{27}$ A chronology beginning at this date was then added to the margins of English editions of the Old Testament so that readers could, at a glance, locate themselves in time. Bossuet's Universal History likewise provided chronologies in the margins that served to date events both by counting up, from Creation and by counting down to the birth of Jesus. (See Figures 1 and 2.)

The chronological scaffolding generated by this computational industry was an important intellectual step, because it provided a ready means for making instant comparisons between the chronologies of different civilizations. The idea was central to the work of some ancient historians and had a significant influence on early modern historians. ${ }^{28}$ In the sixteenth century, Joseph Scaliger and Jean Bodin massaged the existing schemes into a grand system of universal time. The concordances promoted by this work suggested problems with conventional Judeo-Christian dating, for growing contact with Chinese, Indian, and Aztec civilizations was exposing Europeans to time scales that were not counted in the mere thousands of years. Scaliger, for example, pointed out that Chinese cosmology went back more than 880,000 years, and in 1658 the Jesuit Father Martini found that Chinese annals, suitably transposed

${ }^{26}$ What follows relies on Paolo Rossi, The Dark Abyss of Time: The History of the Earth and the History of Nations from Hooke to Vico, trans. Lydia G. Cochrane (Chicago, 1984).

27 Ibid., 144.

${ }^{28}$ Breisach, Historiography, 10, 69-70, 81-82. 


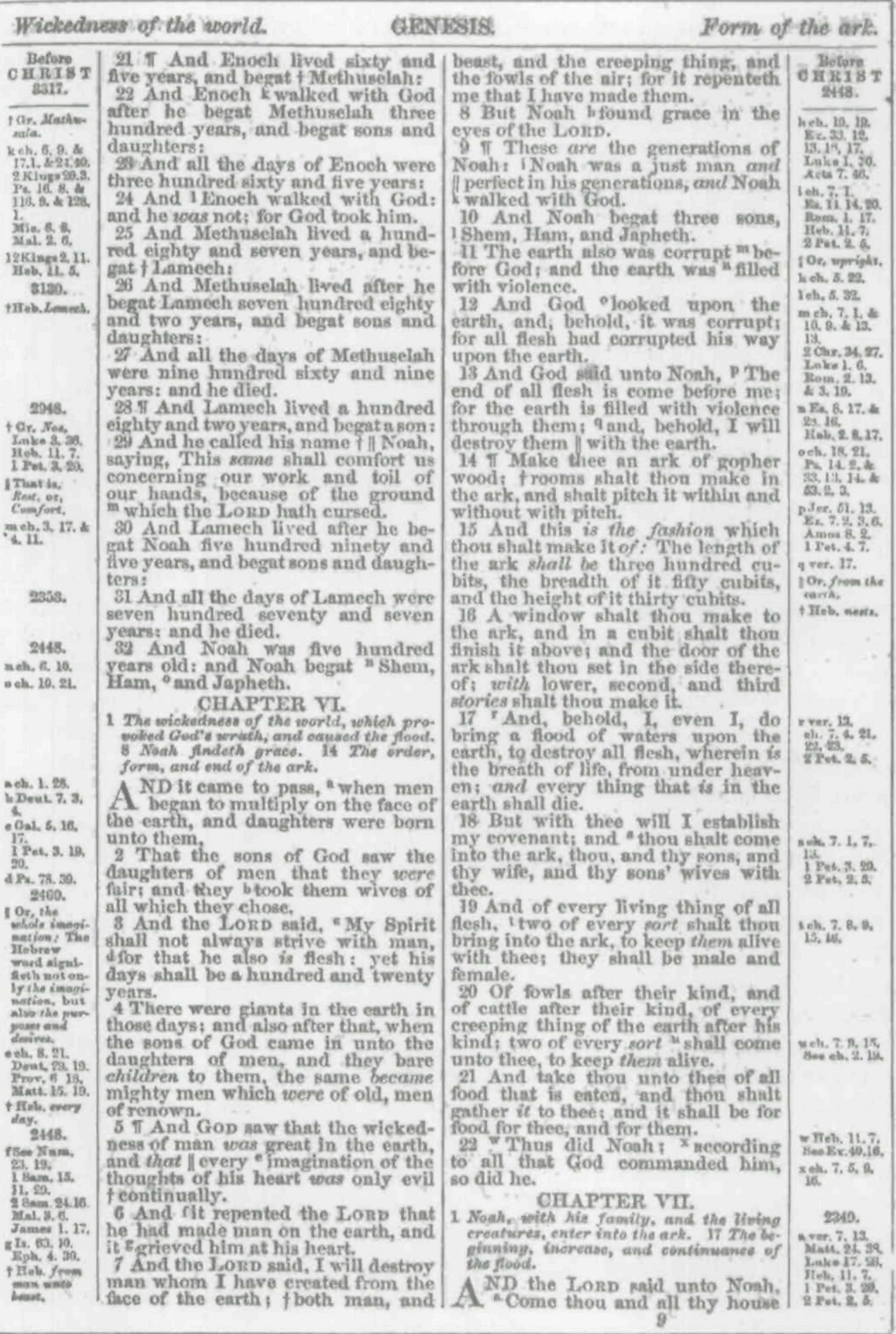

Figure 1: Page from an 1868 edition of the Bible, illustrating marginal dates. Author's collection. 
The earth begins to be filled, and wicked- ${ }_{139}$. M. nefs increafes. Cain, the firft fon of Adam and Eve, fhews the infant world the firft tragical action; and from that time virtue dates her perfecution from vice. There we fee the contrary manners of the two brothers; the innocence of Abel, his paftoral life,

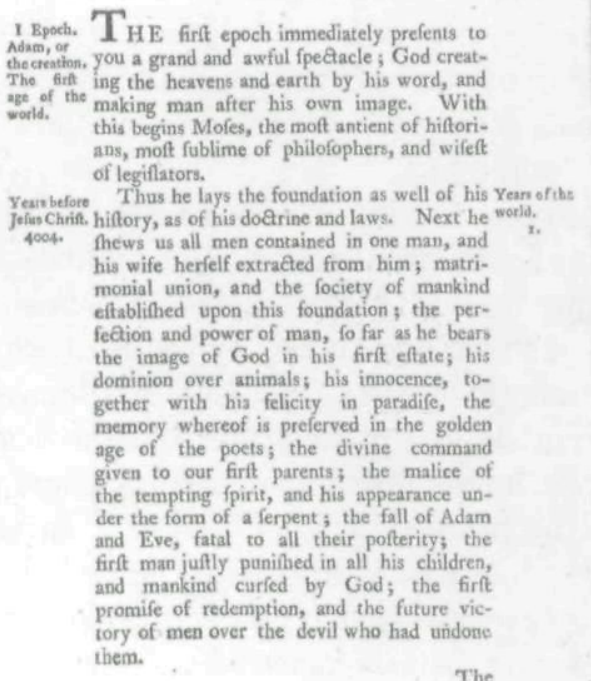
and his offerings arcepted is thole of Cain and his oficrings accepted; thole of cain rejected, his avarice, bis impiety, his fratricide, and jealoufy the parent of murders; the punifhment of that crime, the confeience of the parricide racked with continual terrors; the firft city built by this micreant, now a vagabond won the face of the earth, feeking vagabond upon the lace of the ean he fecking an afylum from the hittred and horror of mankind; the invention of fome arts by his children; the tyranny of paftions, and the prodigious malignity of man's heart, ever prone to evil ; the pofterity of Seth, faithful to God, notwithftanding that depravation: the pious Enoch, miraculoufly fnatched 987 . the pious Enoch, mikculos wot worthy out of the world, which was not worthy of him; the diffinction of the ctildren of God from the children of men; that is, of thofe who lived after the fpirit, from thole who lived after the flefh; their intermixure, and the univerfal corruption of the world, the deftuation of men decreed by a wortd; the deft Gion of men decreed by a juft judgment of God; his wrath denounced againft finners by his fervant Noah; their 2536 . impenitence and hardnefs of heart punifhed 2348. at laft by the deluge; Noah and his famil referved for the reftoration of mankind. This is the fum of what paffed in 1656 years. Such is the beginning of all hiftorics, wherein are difplayed the ommipotence, wirdom and goodnefs of God; innocence happy under his protection; his juftice in avenging crimes, and at the fame time his long-fuffering patience in waiting the converfion of finners; the greatnefs and dignity of man in

Figure 2: Page from Jacques Bénigne Bossuet's An Universal History (1785), illustrating marginal dates. Reproduced courtesy of Fordham University Library.

onto a Christian dating scheme, were reliably recording events that took place more than six hundred years before the Deluge. ${ }^{29}$ Growing awareness of the great antiquity of Sumerian, Chaldean, and Egyptian civilization was equally problematic. Work on Egyptian chronology suggested that Egyptian civilization dated back nearly to the Deluge itself, perhaps even before. How could so sophisticated a civilization have arisen in so short a time? Bodin was much troubled by these problems. The answer that he and others proposed was that all non-Mosaic chronologies either were fabulous or were written in the spirit of envy. ${ }^{30} \mathrm{~A}$ second solution was to prefer the Greek Septuagint over the Hebrew Bible, since the Septuagint allowed an additional 1,440 years. In such ways, the intellectual challenge posed by lengthy Egyptian, Indian, and Chinese chronologies was, at least temporarily, absorbed and overcome.

But challenges to the grip of sacred chronology were not coming from historians alone, for geology, paleontology, ethnology, and natural history also found Ussher's date too constricting. That marine fossils such as shells and sharks' teeth were found on mountaintops had always been something of a problem. One could suppose that they were just odd-looking rocks or freaks of nature laid down by a playful God.

29 Rossi, Dark Abyss, 136, 140.

30 Bodin, Method, 303-333. 
Alternatively, they were carried aloft by the waters of the universal Deluge. Fossils embedded in rock were also a conundrum. By what process could a solid object enter another solid object? For those who admitted the natural origin of such fossils, the solution lay in the proposal that rocks formed in layers through a gradual process of sedimentation. ${ }^{31}$ The resulting realization that layered strata represented geological time did not immediately subvert biblical chronology, since no one knew how long it had taken the layers to form. Imaginative solutions were also devised for other emerging problems, including the tilting of the bedding planes, the discovery of strange creatures such as ammonites, and the presence of humans in the New World. Even so, by the 1750 s, the loosening of the grip of sacred chronology had proceeded to a point where some were postulating an earth that was millions of years old, although such opinions were decidedly in the minority. ${ }^{32}$

The idea of a very old earth was easily dismissed by orthodox Christian theologians and by distinguished scientists alike, for it created as many problems as it solved. Critics seldom failed to notice that mountains had not eroded away in all the time supposedly available. This particular obstacle was solved by the Scottish geologist James Hutton, who argued in the late eighteenth century that mountains were being continually uplifted and continents remade in a process that "has no vestige of a beginning, no prospect of an end." Hutton did not insist on an eternal, uncreated earth. All he claimed was that no trace of the primeval earth could have survived the endless recycling of materials. Eschewing the search for origins, he focused instead on geological mechanisms, in much the same way that conjectural historians typically avoided questions of human origins and instead focused attention on lawlike processes. ${ }^{33}$

Evidence for the antiquity of the earth continued to mount in the early decades of the nineteenth century, and the field of geology developed apace. By the $1840 \mathrm{~s}$, geology's basic chronology, based on the succession of strata, had been worked out by the British geologist Charles Lyell, who published his Principles of Geology in the 1830 s and remained a powerful advocate of uniformitarian geology for the next forty years. Lyell's ideas were contested in his own day, and in 1868 the estimate made by the future Lord Kelvin that a molten earth first consolidated a hundred million years ago - a figure later reduced to twenty to forty million years — put an end to any ideas of an eternal earth. ${ }^{34}$ Yet the Aristotelian idea of an eternal earth has been vindicated in a sense by the current estimate that the earth is around four and a half billion years old, easily old enough to accommodate the gradual geological and biological processes on which people such as Lyell and Charles Darwin were most insistent.

Even as the field of geology was emerging as a science in the first half of the nineteenth century, antiquarians in Denmark, England, and France were excavating

${ }^{31}$ The leading figure here was Nicholas Steno, discussed in Alan Cutler, The Seashell on the Mountaintop: A Story of Science, Sainthood, and the Humble Genius Who Discovered a New History of the Earth (New York, 2003).

${ }^{32}$ See Rossi, Dark Abyss, 109; Claude Albritton, The Abyss of Time: Changing Conceptions of the Earth's Antiquity after the Sixteenth Century (San Francisco, Calif., 1980), 73, 85; Grayson, Establishment, 31-35.

${ }^{33}$ Mott T. Greene, Geology in the Nineteenth Century: Changing Views of a Changing World (Ithaca, N.Y., 1982), 19-45; Rossi, Dark Abyss, 113-118.

${ }^{34}$ Joe D. Burchfield, Lord Kelvin and the Age of the Earth (London, 1975). 
strata in which eoliths (early human stone tools) lay alongside extinct animals such as cave bears and mammoths. ${ }^{35}$ The implications were obvious and had been noted since the very last decade of the eighteenth century. Yet Lyell originally resisted the attempt to associate geological time with human antiquity. A British chauvinist, he dismissed the evidence for man's antiquity compiled by French archaeologists. A sensational archaeological discovery in 1859, this time on English soil, finally convinced the geologists to support the idea of Pleistocene humans. Paleontology and prehistoric anthropology sprang up as legitimate scientific disciplines in the $1860 \mathrm{~s}$, and the proposition that humans had moved through Stone, Bronze, and Iron ages emerged as the fundamental chronological scheme of archaeology. John Lubbock later subdivided the Stone Age into old and new, Paleolithic and Neolithic, the latter associated with the agricultural revolution. Ethnologists such as Lewis Henry Morgan found the long chronology wonderfully liberating and took to it with great enthusiasm. ${ }^{36}$ A crucial element of the time revolution was Darwin's The Origin of Species, published in 1859 , which offered a way to link the history of life and the descent of humanity to the emerging geological time scale, thereby unifying biological time. ${ }^{37}$ The Origin of Species was soon followed by Lyell's Geological Evidences of the Antiquity of Man (1863) and Lubbock's Pre-Historic Times (1865), constituting the three works that lie at the heart of the time revolution of the $1860 \mathrm{~s}$.

THE STAGES OF THE DISCOVERY OF DEEP TIME are well known to historians of science, and figure in the standard disciplinary narratives of the great historical sciences. But what were historians doing as the understanding of time was transformed in the second half of the nineteenth century? Looking back from the early twentieth century, James Harvey Robinson could still reflect on the event with wonder: "Half a century ago, man's past was supposed to include less than six thousand years; now the story is seen to stretch back hundreds of thousands of years." 38 Other historians were at best indifferent. Yet despite the magnitude and implications of the revolution, the question of how historians accommodated deep time had not been seriously addressed until recently.

The later nineteenth and early twentieth century was the great age for patriotic histories of particular nations. In this climate, the urge to write universal histories was partially eclipsed. Even so, a good many works of general history circulated in the United States in the decades following the time revolution of the 1860 s, including works imported from Europe as well as home-grown products. ${ }^{39}$ Some of these were written for the general market. Others-a growing number-were explicitly designed for use in the classroom. Out of this pool of ideas and threads eventually

${ }^{35}$ In addition to works already cited, see A. Bowdoin van Riper, Men among the Mammoths: Victorian Science and the Discovery of Human Prehistory (Chicago, 1993).

${ }^{36}$ Thomas R. Trautmann, Lewis Henry Morgan and the Invention of Kinship (Berkeley, Calif., 1987), esp. 32-35 and 205-230.

37 Ibid., 213.

38 James Harvey Robinson, The New History: Essays Illustrating the Modern Historical Outlook (New York, 1912), 26. On Robinson, see Segal, “'Western Civ,'” esp. 771-779.

${ }^{39}$ For a useful survey of the important general histories of this period, see Charles Kendall Adams, A Manual of Historical Literature (New York, 1882), 31-41. 
emerged the narrative forms that would take shape as Western Civ textbooks, first published in the early decades of the twentieth century. In all these sources we can find clues revealing how some historians reacted to the challenge of deep time.

In an age when so eminent a figure as the geologist Louis Agassiz could persist in his adherence to the idea of divine creation, it would be surprising if all historians accepted the long chronology without demur. The last edition of Royal Robbins's Outlines of Ancient and Modern History on a New Plan (1875), first published in 1830, was uncompromisingly sacred and treated Darwin as an infidel. ${ }^{40}$ Reuben Parsons's Universal History (1902), written for an American Catholic audience, included an unapologetic defense of sacred history. ${ }^{41}$ An especially significant source of resistance came from the great German historian Leopold von Ranke (1795-1886), who continued to affirm the truth of sacred history in his unfinished Universal History. On the other hand, the Oxford historians Edward Freeman and J. R. Green were remarkable for their cautious but sincere and early acceptance of the long chronology. ${ }^{42}$ Amos Dean, in his seven-volume History of Civilization (1868), acknowledged the probability "that human life has existed on the planet during a much longer period than has been generally supposed," even though he perceived no investigative need to breach the barrier created by the Deluge. ${ }^{43}$

Rather than assessing nineteenth-century historians according to the litmus test of belief, however, it behooves us to ask whether the long chronology made any difference to the framing of history. Daniel Segal has argued that few late-nineteenth-century historians made a serious effort to build a meaningful historical continuum bottomed in the deep past. ${ }^{44}$ In the general histories published before 1900 , prehistory was simply tacked on at the beginning, or even reduced to a footnote. ${ }^{45}$ What they offered, moreover, was little enough. In his important Outlines of Universal History (1885), the American historian George Fisher gave just a few paragraphs summarizing recent archaeological discoveries. In a general history first published in 1883, the French historian Victor Duruy, one of Fisher's sources, offered a little more. Even so, his contribution, in the 1925 English edition, amounted to no more than 7 pages in a text 892 pages in length. ${ }^{46}$ One of the most sustained efforts by a historian to summarize the discoveries of archaeology can be found in the tenth edition of the Storia Universale, published in 1884 by the Italian novelist and general historian Cesare Cantù. Cantù was deeply engaged with biological, archaeological, and geological discoveries; the prefatory material is studded with references to scholarship on geological and prehistorical time, and Cantù devoted four chapters to the primitive world and theories about early human society. ${ }^{47}$ But this incorporation of the paleoanthropological evidence was a curiously ironic gesture, because Cantù

${ }^{40}$ Royal Robbins, Outlines of Ancient and Modern History on a New Plan (Hartford, Conn., 1875).

${ }^{41}$ Reuben Parsons, Universal History: An Explanatory Narrative, vol. 1: Ancient History from the Creation of Man until the Fall of the Roman Empire (Yonkers, N.Y., 1902).

${ }^{42}$ See Goldstein, "Confronting Time."

${ }^{43}$ Amos Dean, The History of Civilization, 7 vols. (Albany, 1868), 1: 47, 51.

${ }^{44}$ Segal, " 'Western Civ," "774-775.

45 E.g., Richard Green Parker, Outlines of General History (New York, 1848), 9.

${ }^{46}$ Victor Duruy, General History of the World (New York, 1925). First published in France in 1883, Duruy's Histoire Générale was translated for the U.S. market in 1898 and went through several editions until 1929.

${ }^{47}$ Cesare Cantù, Storia Universale, 10th ed. (Turin, 1884). 
professed an adherence to the truths of sacred history and discussed the paleoanthropological evidence only so as to disprove it.

Cantù's skepticism aside, the problem of incorporating prehistory into the narrative was not just one of belief. It was also one of imagination. One could be open to the idea of deep history without knowing quite what to do with it. A remarkable solution to this narratival difficulty was to reimagine the European Middle Ages as a period of darkness so profound as to duplicate the social state of primitive savagery. In this new schema, ancient history stood in for the golden era of antediluvial sacred history, and medieval Europe was transformed into the primitive world of the immediate postdiluvial age. In an echo of a Huttonian geology that eschewed the search for origins and focused instead on process, general historians of the nineteenth century found that they had no need for genesis and could focus instead on the progress that mankind had made since the most recent catastrophe.

The very idea of a pseudo-primitive Dark Age influenced the ways in which nineteenth-century historians framed the history of civilization. The Enlightenment denigration of the European Middle Ages had made it easy to view the original inhabitants of Europe and the invaders of Rome as crude barbarians, little different from the primitive peoples that figured in conjectural histories and anthropological prehistories. Adam Ferguson made the parallel explicit, describing the Gauls, Germans, and Britons as resembling the natives of North America in their ignorance of agriculture and their tendency to paint themselves and wear the skins of animals. ${ }^{48}$ Edward Gibbon himself wrote of a "deluge of Barbarians." 49 These barbarians gradually came to stand in for Paleolithic man in the developmental schemes of Western history. Medieval historians in the United States, deeply influenced by the idea of biological evolution and geological time, routinely referred to the early Germanic tribes using words such as "primitive." ${ }^{50}$ Doris Goldstein, writing about Freeman and Green, has suggested that "their forays into what they described as the 'primeval' or the 'primitive' were closely related to their interest in the early history of the Teutonic tribes." ${ }^{51}$ Historians used the word in a positive developmental sense, as this 1899 paean to the era makes clear: "in the middle ages we are to see the beginnings of ourselves. We are the perfectly legitimate descendants of mediaeval men, and we have no ideas, no institutions, no manners that are not shot through and through with thread of mediaeval spinning." 52 Nineteenth-century historians were deeply attracted to the idea that progress followed on the heels of a resetting event. All that changed was the event itself, as the aqueous Deluge was transformed into a deluge of barbarians.

This is not the place to explore in detail the refashioning of the European Middle Ages in nineteenth-century historiography. Here it is enough to suggest that medieval Europe's capacity to serve as a doppelganger for the primitive past helps

48 Ferguson, An Essay, 75.

49 Edward Gibbon, The Decline and Fall of the Roman Empire, abridged by D. M. Low (New York, 1962), 524-525.

so In general, see Gabrielle Spiegel, "L'histoire scientifique et les utilisations antimodernistes du passé dans le médiévisme américain," Cahiers du Centre de Recherches Historiques, Réflexions Historiographiques 22 (1999): 87-108.

51 Goldstein, "Confronting Time," 25.

52 Arthur Richmond Marsh, "Special Introduction," in Henry Hallam, History of Europe during the Middle Ages, rev. ed. (New York, 1899), 1: iv-v. 
explain why some historians failed to engage more seriously with the Paleolithic. Another problem with the Paleolithic lay in the inability of prehistorians to date their findings with confidence, since the lack of a chronological scaffolding made it impossible to attach prehistory to the grid of historical time, as J. L. Myres noted in $1911 .{ }^{53}$ Yet the most prominent obstacle to the incorporation of prehistory centered on how nineteenth-century historians imagined the evidence appropriate for the study of history. ${ }^{54}$ Since the seventeenth century, when schemes for lengthening the age of the earth first began to circulate, the "time beyond history" has been dismissed as unknowable. "All of that time was unknown and concealed," remarked Philippe Le Prieur in 1656.55 Turgot said much the same. Vico denied the possibility of approaching the time before the Deluge via the products of vernacular language, since all such languages postdated the Deluge. Nineteenth-century archaeologists spoke of the fog that obscured their vision of the pre-Christian era. Lubbock summed up the philosophy of those opposed to prehistoric archaeology in the opening paragraph of Pre-Historic Times:

The first appearance of man in Europe dates from a period so remote, that neither history, nor even tradition, can throw any light on his origin, or mode of life. Under these circumstances, some have supposed that the past is hidden from the present by a veil, which time will probably thicken, but never can remove ... Some writers have assured us that, in the words of Palgrave, "We must give it up, that speechless past." ${ }^{56}$

That speechless past: no other phrase could capture so well the skeptical attitude toward the possibility of studying time beyond the veil.

Lubbock's comment on the prejudices that hampered the acceptance of prehistoric archaeology aptly describe the epistemological stance taken by Leopold von Ranke. In the remarkable opening paragraph of his Universal History, published in the 1880 s, Ranke deliberately refused to breach the veil of prehistory:

History cannot discuss the origin of society, for the art of writing, which is the basis of historical knowledge, is a comparatively late invention. The earth had become habitable and was inhabited, nations had arisen and international connections had been formed, and the elements of civilization had appeared, while that art was still unknown. The province of History is limited by the means at her command, and the historian would be over-bold who should venture to unveil the mystery of the primeval world, the relation of mankind to God and nature. The solution of such problems must be intrusted to the joint efforts of Theology and Science. ${ }^{57}$

Or in the words of the French historians Charles Langlois and Charles Seignobos: "The historian works with documents. Documents are the traces which have been left by the thoughts and actions of men of former times ... For want of documents

53 J. L. Myres, The Dawn of History (New York, 1911), 8-10.

54 Segal, "'Western Civ,"” 774-775.

55 Quoted in Rossi, Dark Abyss, 159.

56 John Lubbock, Pre-Historic Times, as Illustrated by Ancient Remains, and the Manners and Customs of Modern Savages, 2nd ed. (New York, 1872), 1.

57 Leopold von Ranke, Universal History: The Oldest Historical Group of Nations and the Greeks, ed. G. W. Prothero, trans. D. C. Tovey and G. W. Prothero (New York, 1885), ix. 
the history of immense periods in the past of humanity is destined to remain for ever unknown. For there is no substitute for documents: no documents, no history." 58

No documents, no history. A feature of Vico's New Science, this epistemological stance was repackaged by Ranke and others in the nineteenth century and promulgated as a basis for scientific history. Admittedly, not all of Ranke's contemporaries shared this point of view. ${ }^{59}$ So how did Ranke and others arrive at this stance? One can, with Herbert Butterfield, point out that Ranke was trying to preserve the realm of history from the speculations of philosophers. ${ }^{60}$ But it is important not to lose sight of the fact that Ranke, like Vico, accepted the truths of sacred history. Early chapters of Universal History echo the sacred histories of the seventeenth and eighteenth centuries. Ranke's firm belief that "the course of history revealed God's work," in Peter Novick's phrase, is well known. ${ }^{61}$ In other words, Ranke arguably promoted writing as the sole reliable basis of historical knowledge, not just because he sought to place history on a scientific footing, but also because this was the only way he knew how to exclude prehistorical artifacts from historical reckoning and thereby dodge the vexed theological questions created by biology and archaeology.

IN ITS ATTITUDE TOWARD EVIDENCE, an important strand of late-nineteenth-century scientific history embedded a resistance to deep time under the guise of a neutral professionalizing agenda. By the turn of the century, however, some of the intellectual obstacles to prehistory were fading. The discovery of cave paintings in the 1870 s and 1880 s was a jolt to those who doubted the humanity of Paleolithic humans, because the capacity to create art was seen as a symbol of a higher world viewevidence for the thinking, feeling human so difficult to detect in the eoliths and bones that had hitherto dominated the archaeological world. ${ }^{62}$ Lord Kelvin's thermodynamic principles had done away with the idea of an ageless earth, and although his dates proved wrong, it was nonetheless clear that the earth had a datable point of origin that was immensely old. Prehistorical dates were circulating widely in the works of acknowledged authorities such as Sir Arthur Keith, and although these, too, were inaccurate, they nonetheless provided a chronological scaffolding on which historians could begin to build. ${ }^{63}$ (See Figure 3.) The tendency to focus exclusively on the political or constitutional history of nations was being challenged by the rise of social and economic history, fields that focused on how people lived in the past, not just on how they were governed.

In the wake of these changes, the New History of the 1910 s and 1920 s saw some remarkable attempts to bridge the gap between prehistory and history. In 1913, the

58 Charles V. Langlois and Charles Seignobos, Introduction to the Study of History, trans. G. G. Berry (New York, 1898), 17. See also 145: "A document only contains the ideas of the man who wrote it ... We thus arrive at this general rule of method: the study of every document should begin with an analysis of its contents, made with the sole aim of determining the real meaning of the author."

59 Goldstein, "Confronting Time," 13, 18.

${ }^{60}$ Butterfield, Man on His Past, 103-104.

${ }^{61}$ Peter Novick, That Noble Dream: The "Objectivity Question" and the American Historical Profession (Cambridge, 1988), 27; see also Breisach, Historiography, 233.

62 John Pfeiffer, The Creative Explosion: An Inquiry into the Origins of Art and Religion (New York, 1982), 19-39; Grahame Clark, World Prehistory in New Perspective (Cambridge, 1977), 3-4.

${ }^{63}$ Sir Arthur Keith, New Discoveries Relating to the Antiquity of Man (1915; repr., New York, 1931). 
English historian James Bryce spoke enthusiastically about the possibility of a chronological expansion of the historians' terrain. ${ }^{64}$ In 1916, the Berkeley historian Frederick Teggart suggested that "the historian has come to see that there is no hard and fast boundary between 'historic' and 'prehistoric' times, between 'historical' and 'unhistorical' peoples; the history of Man includes man everywhere and at all times ... Anthropology and History differ only in so far as each represents the use of a special investigative technique." 65 At the same time, in his New History, Robinson was arguing forcefully for a historical understanding that would embrace the Paleolithic, and castigated his peers for their failure to make the mental switch:

There may still be historians who would argue that all this has nothing to do with history,that it is "prehistoric." But "prehistoric" is a word that must go the way of "preadamite," which we used to hear. They both indicate a suspicion that we are in some way gaining illicit information about what happened before the footlights were turned on and the curtain rose on the great human drama. Of the so-called "prehistoric" period we, of course, know as yet very little indeed, but the bare fact that there was such a period constitutes in itself the most momentous of historical discoveries. ${ }^{66}$

If the time revolution of the 1860 s had caused the bottom to drop out of history, "prehistory and its living representatives were a means of 're-bottoming' history." This is how Daniel Segal has characterized the result of Robinson's engagement with the long chronology. ${ }^{67}$ In this schema, the primitive conditions of the Paleolithic are an essential element of the story of Western Civilization, because they serve as a convenient measure for our subsequent progress.

There is much truth to the argument that the New History was thoroughly permeated by a rejection of the short chronology. Certainly, the paragraph or two devoted to prehistory in nineteenth-century works such as Fisher's Outlines of Universal History generally grew to a short chapter or more in the textbooks and professional histories published in the United States after the $1920 \mathrm{~s} .{ }^{68}$ Yet when Robinson actually applied this idea in his own textbook, An Introduction to the History of Western Europe, first published in 1903, the results proved to be quite otherwise. Consider the question posed at the very outset:

One of the most difficult questions that a historical writer has to settle is the point at which he is to begin his tale ... How far back shall we go to get a start? Modern research seems to show that man was a wandering, hunting animal for hundreds of thousands of years before he learned to settle down and domesticate animals, cultivate the soil, and plant and reap crops. ${ }^{69}$

So where did Robinson begin? The answer is perhaps inevitable: the European Middle Ages. Eschewing the need to return to the Paleolithic bottom, Robinson argued that because our civilization has descended directly from the fusion of Roman civ-

${ }^{64}$ Goldstein, "Confronting Time," 21-24.

${ }^{65}$ Frederick J. Teggart, Prolegomena to History: The Relation of History to Literature, Philosophy, and Science (Berkeley, Calif., 1916), 276.

${ }^{66}$ Robinson, New History, 56.

67 See Trautmann, Lewis Henry Morgan, 221; Segal, “'Western Civ,'” 772, 775, 779.

${ }^{68}$ In general, see Segal, “ 'Western Civ.'” Robinson himself cited favorably the 250 pages devoted to anthropology in Eduard Meyer's History of Antiquity; see Segal, “'Western Civ,'” 89.

${ }^{69}$ I consulted the 1924 revised and enlarged edition of An Introduction to the History of Western Europe (Boston, 1924). 


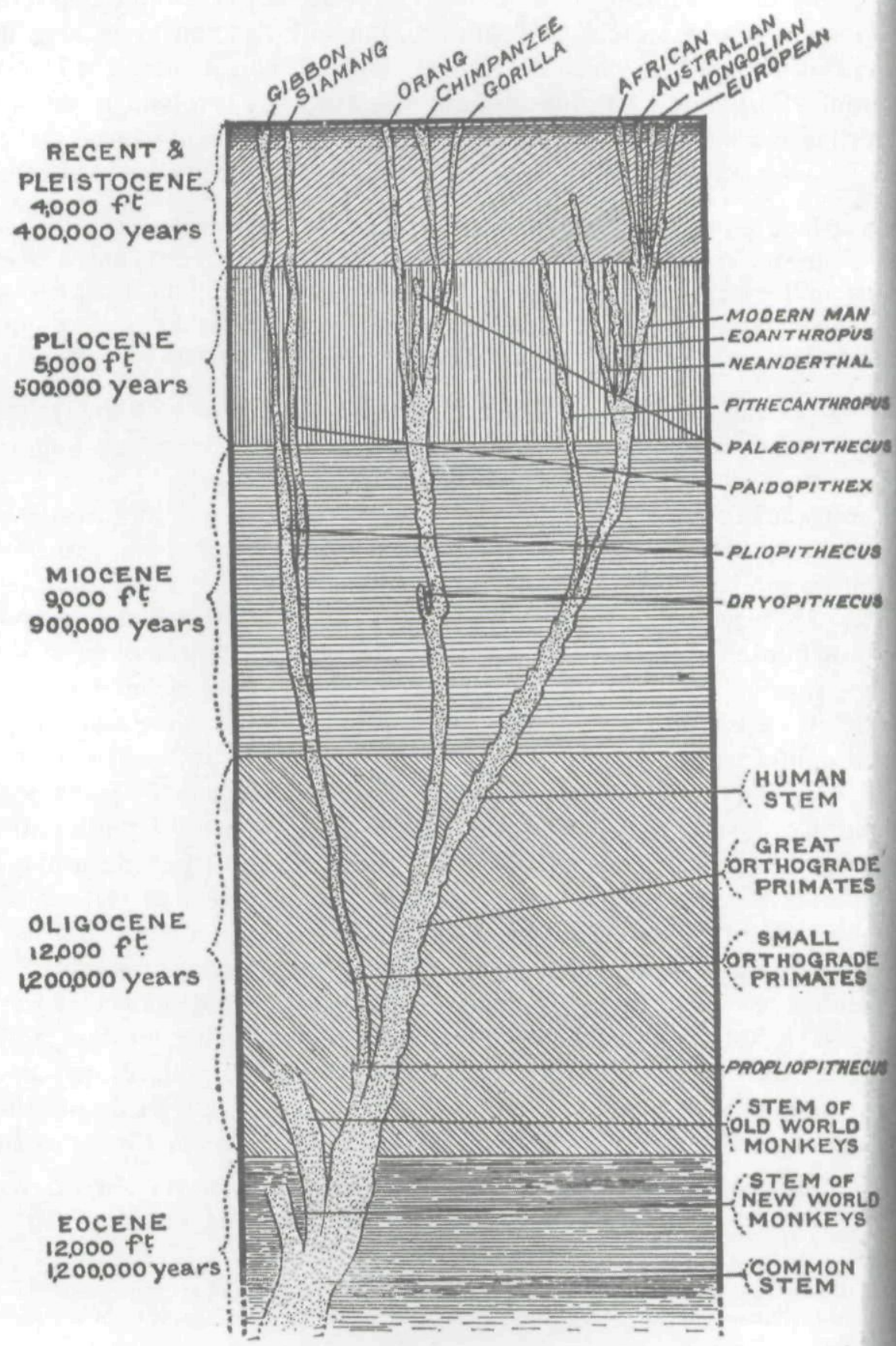

Genealogical tree, showing the ancestral stems and probable lines of descent of the higher primates.

FIgURE 3: The family tree of hominins, from the 1920 edition of Sir Arthur Keith's The Antiquity of Man. Reproduced courtesy of Fordham University Library. 
ilization and medieval Europe, there is no particular need to go any earlier. ${ }^{70}$ Recapitulating this argument in The Ordeal of Civilization (1926), he noted that "the development of our present civilization began with the first inventions and findings-out of mankind, of which no records remain." This is the great Rankean conundrum. "Fortunately," Robinson went on to say, "we can take up the story with the decline and break-up of the Roman Empire." "11 Subsequent passages reveal Robinson's assessment of where medieval Europe belongs on the scale of civilization:

It seemed for a few years as if the new German kings ... would succeed in keeping order and in preventing the loss of such civilization as remained. But no such good fortune was in store for western Europe, which was now only at the beginning of the turmoil which was to leave it almost completely barbarized, for there was little to encourage the reading or writing of books, the study of science, or attention to art, in a time of constant warfare and danger. ${ }^{72}$

Much like earlier historians who had chosen to begin history with the Deluge, Robinson sought to find the primitive in medieval Europe so as to have a more recent bottom on which to build history's narrative of progress.

Robinson, in other words, never really overcame the idea of rupture, the idea that some gulf separates us from the Paleolithic. With rare exceptions, textbooks and general histories published over the twentieth century followed more or less in his footsteps. ${ }^{73}$ The gulf between prehistory and history was justified in a variety of ways. Robinson himself, thinking in a Rankean mode, made an epistemological distinction between remains and written documents. ${ }^{74}$ Other historians claimed that documentary archives are more authoritative because their contents were explicitly designed to record information about the past. In the words of the authors of The Illustrated World History (1935), these constitute "conscious records." 75 Some have even claimed that the archive itself must be official, the product of intention. In a letter to a fellow historian written in 1927, J. Franklin Jameson rejected social history on the grounds that "you do not have definitely limited bodies of materials, handed down by authority, like statutes or other manageable series, but a vast blot of miscellaneous material from which the historian picks out what he wants."76

Another reason justifying the gulf between history and prehistory was lucidly expressed in Robert H. Labberton's Universal History, first published in 1871 and reprinted over the next few decades. Aware of the true depth of the human race, Labberton nonetheless held that a society can be subject to the gaze of history only when the society itself has a historical consciousness. ${ }^{77}$ In The Columbia History of

${ }^{70}$ Ibid., 8-9. On Robinson's fusion of medieval with primitive, see also the brief remarks of Gilbert Allardyce, "The Rise and Fall of the Western Civilization Course," AHR 87, no. 3 (June 1982): 704-705.

71 James Harvey Robinson, The Ordeal of Civilization (New York, 1926), 7.

72 Ibid., 35. See also 47 and 90.

73 The most noteworthy exception among Western Civ textbooks is Harry Elmer Barnes, The History of Western Civilization, 2 vols. (New York, 1935), which was quite serious in its incorporation of the Paleolithic.

${ }^{74}$ Segal, "'Western Civ,'” 779. One can still find variants on the Rankean argument; most recently, see Duiker and Spielvogel, Essential World History, 3.

75 John Hammerton and Harry Elmer Barnes, eds., The Illustrated World History: A Record of World Events from Earliest Historical Times to the Present Day (New York, 1935), 7.

${ }^{76}$ Quoted in Novick, That Noble Dream, 89-90.

77 Robert H. Labberton, Labberton's Universal History, from the Earliest Times to the Present (New York, 1902), xxi. See also François Pierre Guillaume Guizot, A Popular History of France, from the Earliest Times, trans. Robert Black (Boston, 1869), 1: 15. 
the World, published a century later, the argument appears in this form: "History exists only in a persisting society which needs history to persist." 78 The consciousness of history, according to this argument, was itself a catalytic device that propelled humans across the gulf.

Still other historians echoed an argument that Fisher made in 1885 in his Outlines of Universal History, designed explicitly for use as a textbook in American secondary schools:

History is concerned with the successive actions and fortunes of a community; in its broadest extent, with the experiences of the human family. It is only when men are connected by the social bond, and remain so united for a greater or lesser period, that there is room for history. It is, therefore, with nations, in their internal progress and in their mutual relations, that history especially deals. Of mere clans, or loosely organized tribes, it can have little to say. ${ }^{79}$

In 1909, John Bagnall Bury elevated this to a more systematic philosophy, arguing that anthropology dealt with presocial humans, whereas history "deals only with the development of man in societies." 80 Bury argued that the characteristic feature of society was the "differentiation of function" or division of labor, evidently assuming that primitive societies made no such distinctions. Still another argument held that early humans were not fully human, and that some event transformed them suddenly into civilized man. Consider Hermann Schneider's general history of world civilization, first published in German in 1927 and translated into English in 1931:

There have been man-like creatures of the human breed (pre-humans, ape-men) for tens of thousands of years, nay, hundreds of thousands of years, before the Ice Age. Human beings proper have existed only since the end of the Ice Age; only then did ape-man develop into man on the road to civilization... Herein man surpasses the brutes; no animal before him ever took that step: here is the dividing-line between brutes and men. ${ }^{81}$

Schneider's views are an extreme version of a bias built into many world histories of the early twentieth century, namely, that humans were not quite human before civilization. It was civilization that made humanity, not humanity that made civilization.

This account embeds another perspective that was and remains common in a variety of twentieth-century general histories. In the nineteenth century, "prehistoric" meant "undocumented." A new shade of meaning was added in the twentieth, for "prehistoric" also came to mean a time before history, as if history had not moved in the eons before civilization. Current in some anthropological circles around the turn of the century was the belief that progress itself was highly unusual-authors such as Henry Sumner Maine and Walter Bagehot spoke instead of stationary societies and "fixity." Several decades later, Oswald Spengler wrote of a culture in stasis as being caught within a "historyless" period. ${ }^{82}$ Ideas such as these, when applied to the deep past, constitute the myth of Paleolithic stasis.

78 Garraty and Gay, The Columbia History of the World, 49.

79 George Park Fisher, Outlines of Universal History, Designed as a Text-Book and for Private Reading (New York, 1885), 1.

80 John Bagnall Bury, "Darwinism and History," in Bury, Selected Essays of J.B. Bury, ed. Harold W. V. Temperley (Cambridge, 1930), 32 n. 1. Similar ideas can be found in Max Savelle, ed., A History of World Civilization (New York, 1957), 1: 28.

${ }^{81}$ Hermann Schneider, The History of World Civilization from Prehistoric Times to the Middle Ages, vol. 1, trans. Margaret M. Green (New York, 1931), 3.

82 Breisach, Historiography, 398. 
The myth of Paleolithic stasis configured humanity's deep past as a grim and changeless era. The authors of a world history textbook for use in Catholic secondary schools, published in 1958, conveyed the idea nicely:

Our imagination fails us when we try to see in the mind's eye the uncounted generations of Paleolithic people. We know what men have proved capable of accomplishing - their sciences and arts and great civilizations. Why, then, did they live for so long in the wilderness? It appears as if some great calamity had fallen upon human nature itself, as if some sentence of banishment and damnation had been laid on man by his Creator. ${ }^{83}$

Paleolithic stasis, in this view, was a result of the Fall. But what broke the stasis and set man on the move? Rather than catastrophe, some general histories of the twentieth century proposed the idea of a catalyzing event that introduced progress or direction into a society hitherto without history. Mott Greene characterizes the argument in this way: "at some point a leap took place, a mutation, an explosion of creative power-the 'discovery of mind,' or the 'birth of self-consciousness'-interposing a barrier between us and our previous brute, merely biological existence." ${ }^{84}$ For the author of $A$ Brief History of Civilization (1925), the events that brought mankind out of the "darkness" included the arrival of the Aryan race on the scene. ${ }^{85}$ Schneider waffled between environmental changes and the fortuitous blending of human stocks. ${ }^{86}$ In the more recent Penguin History of the World, J. M. Roberts postulates a new capacity for making conscious choices, a transformation that broke through what hitherto had been the dominating influence of genes and environment. ${ }^{87}$

An especially important catalyzing event was the invention of writing. ${ }^{88}$ Eighteenth-century general historians were not particularly sensitive to the invention of writing as a historical event. By the nineteenth century, however, the invention of writing was beginning to figure prominently in historical accounts. ${ }^{89}$ In 1928, Geoffrey Parsons introduced his chapter on the dawn of civilization in this way: "After 100,000 years of savagery and 10,000 years of barbarism the beginnings of writing and of civilization appeared at the eastern end of the Mediterranean." 90 Schneider identified the art of working in metal and writing as crucial events in Near Eastern history. ${ }^{91}$ In later accounts, writing was thought to have allowed humankind to preserve valuable learning for posterity, and thus, for the first time, to have permitted human civilization to build upon itself in rapid Lamarckian fashion. ${ }^{92}$ Historians such as Ranke had long argued that writing alone made the past knowable.

${ }^{83}$ Ross J. S. Hoffman, ed., Man and His History: World History and Western Civilization (Garden City, N.Y., 1958), 28.

${ }^{84}$ Greene, Natural Knowledge, 3.

85 John S. Hoyland, A Brief History of Civilization (London, 1925), 24, 48, 49.

${ }^{86}$ Schneider, The History of World Civilization, 7.

${ }^{87}$ J. M. Roberts, The Penguin History of the World, 3rd ed. (London, 1995), 4. This argument, common to many general histories, may have been influenced by Julian Jaynes's The Origin of Consciousness in the Breakdown of the Bicameral Mind (Boston, 1976).

${ }^{88}$ Sumeria was the earliest region to develop writing, a little more than five thousand years ago. Writing was independently invented elsewhere.

89 E.g., Henry Thomas Buckle, History of Civilization in England (New York, 1860), 1: 214-218.

${ }_{90}$ Geoffrey Parsons, The Stream of History (New York, 1928), 142.

91 Schneider, The History of World Civilization, 37-38.

${ }^{92}$ See, among others, Crane Brinton et al., eds., A History of Civilization, vol. 1: Prehistory to 1715 (New York, 1955), 18; Shepard Bancroft Clough et al., eds., A History of the Western World (Boston, 1964), 14. 
The belief in writing as a catalyzing event, however, was a much more profound concept. Writing, in this view, actually put civilization on the move and created history out of the historyless Paleolithic. Few historians, it seems, were troubled by the incongruities of this argument: that agriculture, villages, towns, even cities and empires arose before the invention of writing; that the earliest forms of writing consisted of such things as market transactions and tax records, with no moral, political, or legal lessons for future generations; that the great religious texts and myths circulated in oral form long before they were written down.

The emphasis given to the invention of writing in historical accounts was linked to another trend, a key element of the persisting chronogeography of sacred history. This was the growing inclination to locate the Garden of Eden in Mesopotamia. (See Figure 4.) In medieval Europe, virtually all observers had associated the Garden of Eden with the Far East. Over time, it shifted westward in popular geography, toward the Near East, where both Bodin and Vico were inclined to place it. Armenia was the location preferred by the church historian George Smith in his The Patriarchal Age (1847). ${ }^{93}$ In Smith's case, the reasons for this shift are especially interesting. Armenia, he noted, is where Noah and his sons settled after the Deluge. In this vision, the Ark, scarcely drifting at all in the floodwaters, settled on Mount Ararat after the waters subsided. Smith was insistent on Armenia because it was close to the geographic roots of the Indo-European peoples-and hence better suited to his purpose, which was to argue that the historical splitting of the Indo-European linguistic family was identical to the Confusion of Tongues. ${ }^{94}$ Twentieth-century history and archaeology would soon arrive at a consensus that Mesopotamia was the birthplace of writing. The Sumerian origins of writing joined with the relatively new myth of a Mesopotamian Eden in confirming the Near East as the cradle of humanity. The rise of Mesopotamia in twentieth-century historiography is palpable. General histories and textbooks published in the later nineteenth century typically had history begin in Egypt, then considered the oldest civilization. ${ }^{95}$ In most postwar textbooks, however, Mesopotamia supplanted Egypt as the point of origins. ${ }^{96}$

The deep gulf separating the Stone Age from civilization, a backward nowhere from a progressive Mesopotamia, was humanity's Rubicon. Crossing it at some point late in the Neolithic era, humanity entered on the road to civilization, creating history in the process. The Neolithic Rubicon performs a narrative function eerily similar to the Deluge. There are some obvious differences. The Deluge was a resetting

93 George Smith, The Patriarchal Age; or, The History and Religion of Mankind, from the Creation to the Death of Isaac (London, 1847), 165-167.

${ }^{94}$ See ibid., 384-415, esp. the discussion of Sir William Jones from 401 onward.

${ }_{95}$ Among the many exemplars of textbooks or pedagogies that begin the course of study with Egypt, see W. C. Taylor, A Manual of Ancient and Modern History (New York, 1852); John MacCarthy, History of the World from the Earliest Period to the Present Time (New York, 1882); Philip Van Ness Myers, Ancient History (Boston, 1904); Labberton, Labberton's Universal History; and Herbert Darling Foster et al., eds., A History Syllabus for Secondary Schools (Boston, 1904). Lynn Thorndike includes two chapters on the prehistoric era in his A Short History of Civilization (New York, 1930) but then proceeds to Egypt. Some early texts, including Fisher, Outlines of Universal History, begin with China and India, then move to Egypt.

${ }_{96}$ Among the many examples, see Clough et al., A History of the Western World (1964), and Garraty and Gay, The Columbia History of the World (1972). The fourth and most recent edition of William H. McNeill, A World History (Oxford, 1999), begins with Mesopotamia, in the valley of the Tigris and Euphrates, as does Duiker and Spielvogel, Essential World History. 
event, plunging humanity into the primitive conditions demanded by conjectural history. The Neolithic Rubicon was a passage from stasis to progress. But both sit astride the buffer zone between nonhistory and history. Both act as a rupture, generating a discontinuous narrative.

By this analysis, the Paleolithic "bottom" to the narrative of Western Civ has always been a false bottom. Robinson was earnest in his desire to integrate the Paleolithic into the stream of history, but in his own textbooks he was perfectly content to use the European Middle Ages as the Western world's point of origin. Even as Robinson was perfecting his textbooks, however, others were having a go at rebuilding the narrative of history, and coming up with very different results. In the $1920 \mathrm{~s}$, the reading public was fascinated by the vertiginous prospects of deep history. Some measure of this fascination can be found in the phenomenal success of H. G. Wells's The Outline of History, whose first edition was published in 1919. From his opening chapter, Wells rooted history in deep geological, even astronomical, time; he devoted far more attention to the Paleolithic and Neolithic than did other histories of his day. Moving continuously from geological and biological time to historical time, the narrative does not postulate a rupture. Several books and series published in the wake of Outline were equally ambitious and equally seamless. A remarkable exemplar is "The Corridors of Time," a series of ten books published between 1927 and 1956 by Yale University Press. Beginning with a volume entitled Apes and Men, the series develops a natural history of humanity that runs down to the agricultural revolution and beyond. In The Stream of History, a general history published by Scribner's in 1928, Geoffrey Parsons devoted 142 pages, a quarter of the total, to prehistory. These and other works entered the space first opened by Wells. ${ }^{97}$ The modern-day descendants of this narrative include best-selling trade histories written by Jared Diamond and other authors without a disciplinary affiliation with history. ${ }^{98}$

As William T. Ross has pointed out, Outline, with its frank Darwinian message, was aimed at a middlebrow audience "obstinately unwilling to subordinate itself to any older 'blue-blood' elite." 99 The response was immense: the work sold 150,000 copies in its initial English edition and 500,000 copies in the subsequent U.S. edition. The work's appeal lay in the message that biology, not genius, was responsible for getting us where we are today. ${ }^{100}$ This was an explicit attack on the university-educated political elite, who were inclined to explain history's progressive direction as a function of six thousand years of careful political stewardship. Political elites were not necessarily anti-Darwinian. They favored the older narrative, suitably shorn of its sacred underpinnings, for the political myth it conveyed. Leaderless, man is doomed to live in an unchanging Paleolithic world. Properly submissive to the benevolent rule of far-seeing college-educated elites, mankind ascends the ladder of civilization.

The captivating possibility of Ross's argument is that the historians responsible for writing and teaching the first generation of Western Civ textbooks had political

${ }^{97}$ See also G. Elliot Smith, Human History (New York, 1929).

98 Jared Diamond, Guns, Germs, and Steel: The Fates of Human Societies (New York, 1997). See also John Reader, Africa: A Biography of the Continent (New York, 1998); Tim Flannery, The Eternal Frontier: An Ecological History of North America and Its Peoples (New York, 2001).

${ }_{99}$ William T. Ross, H.G. Wells's World Reborn: The Outline of History and Its Companions (Selinsgrove, $\mathrm{Pa}$., 2002), 16.

100 Ibid., 20. 


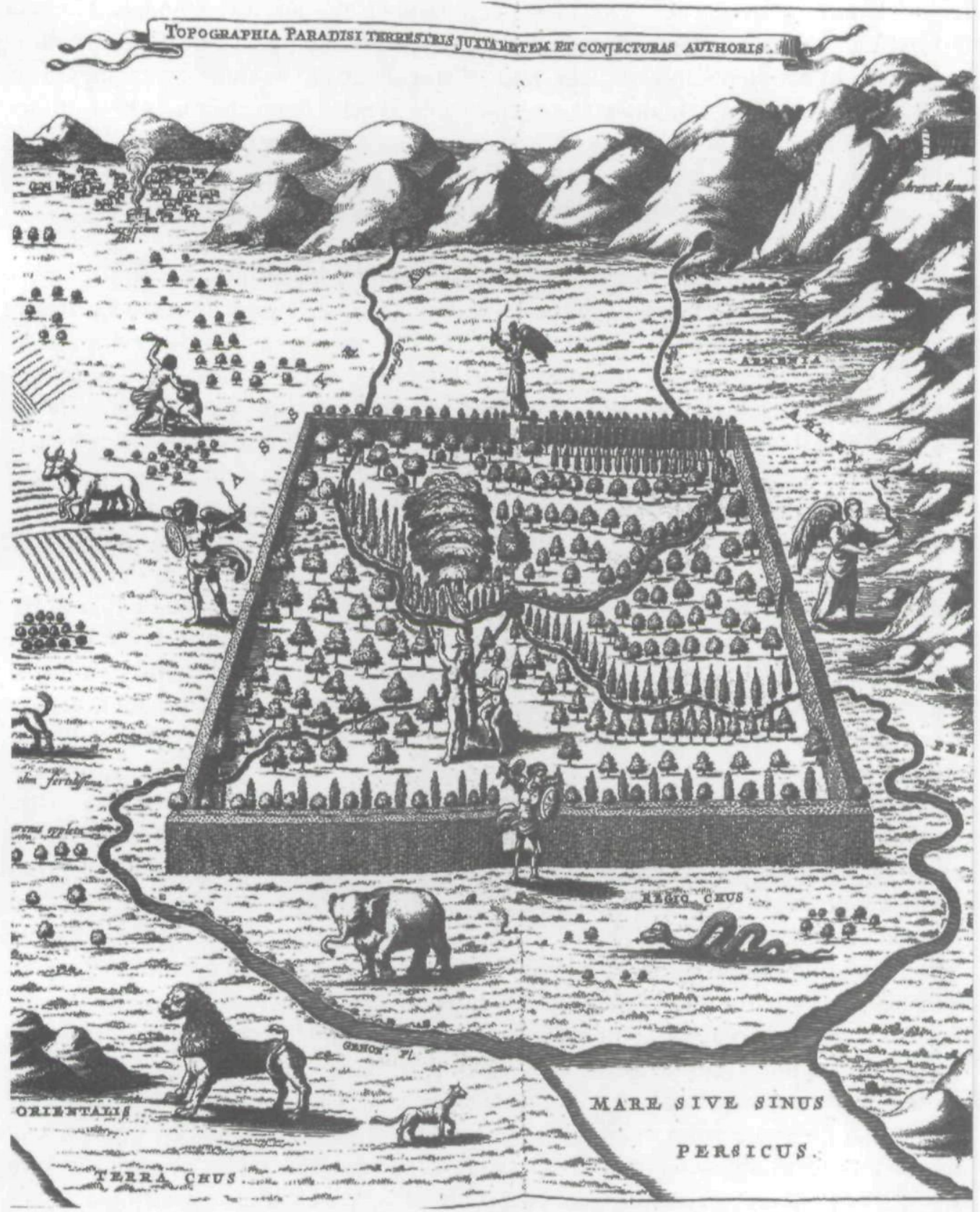

FIgURE 4: The Garden of Eden in Mesopotamia. From Athanasius Kircher, Arca Noë. Reproduced courtesy of Fordham University Library Special Collections.

motivations for placing the Paleolithic on the other side of a gulf. Adopting the long chronology, after all, might invite the dangerous idea that political hierarchies emerged as the result of natural or Darwinian processes. To believe this would be to doubt the civilizing function of education, the blessing that is writing-even the beneficent role of academia itself. 
BY THE EARLY TWENTIETH CENTURY, most professional historians had abandoned sacred history. Yet the chronogeography of sacred history and its attendant narrative of rupture has proven to be remarkably resilient. History still cleaves to its short chronology. The otherwise meaningless date of 4000 B.C. continues to echo in our histories. ${ }^{101}$ Authors still use the narrative device of rupture to create an artificial point of origin, reducing the Paleolithic to the status of a prologue to history, humanity's "apprenticeship." And history's point of origin is still a Mesopotamian origin. Although we may have abandoned the sacred, we have not yet escaped the grip of sacred history.

The obstacles that once prevented the absorption of deep time have, for the most part, disappeared. New research in the genetic and archaeological archives has transformed a once undifferentiated past of several million years into a past punctuated by extraordinary events and adventures, making it difficult for anyone to maintain a belief in a changeless Paleolithic. The mid- to late Paleolithic has now been dated with considerable precision, making available the scaffolding that nineteenth-century historians never had. Recent archaeological research has demonstrated the existence of late Paleolithic villages and towns numbering in the hundreds, even thousands, of people, proving that complex political organization owes nothing to agriculture, still less to the invention of writing. More recent civilizations and societies, equally undocumented but nonetheless knowable through archaeological research and oral history, figure prominently in the many branches of world history, illustrating how historians no longer consider documents essential to the framing of history. Ancient history is unimaginable without the archaeological evidence; medieval history is very nearly so; and the effort to reconstitute the histories of the peoples without writing is one of the signal achievements of twentieth-century history. An appreciation for oral composition and social memory suggests just how little the technology of writing has actually added to our ability to recall and duplicate the lessons of the past. One could go on. Even with the minimal evidence at his disposal in 1919 , Wells showed how it was possible to build a history that seamlessly links the deep past to the recent past. Rather than Ranke's epistemological rupture, demarcating the unknowable from the knowable, one should imagine a cone of increasing evidence, swollen but not fundamentally transformed in recent millennia by the addition of writing. To learn to think with this cone, all one need do is acknowledge that writing is not superior to the other historical traces that our colleagues in the other historical disciplines use to approach the past.

What do we gain from incorporating the deep history of humanity more firmly into history texts and syllabuses? To do so is to foster a new interdisciplinarity, one that will not only reframe our narratives of the deep past but also contribute to the histories of Postlithic societies. Important features of modern political and social behavior-gossip and communication, altruism and cooperation, dominance hierarchies, women and sex, disease, even religion-are illuminated when set into relief

101 For a few examples, see Harry Elmer Barnes, An Intellectual and Cultural History of the Western World, 3rd rev. ed., vol. 1: From Earliest Times through the Middle Ages (New York, 1965), 39; C. Harold King, A History of Civilization: Earliest Times to the Mid-Seventeenth Century-The Story of Our Heritage (New York, 1956), 4-5. The first unit of New York State's Global History and Geography curriculum for ninth and tenth grade begins in 4000 B.C. (see http://www.emsc.nysed.gov/ciai/socst/pub/sscore2.pdf, p. 94, accessed June 10, 2005). 
on the canvas of the Paleolithic. ${ }^{102}$ Authors working from the perspectives of paleoanthropology, geography, climatology, population genetics, and evolutionary psychology have begun to plot the early history of humankind in astonishingly vivid detail, and in the process have developed powerful new arguments tying the deep past to the present. Postlithic history will be enriched by these perspectives.

Aside from the benefits of building a genuine interdisciplinary history of humanity, we are left with the political or moral implications of failing to break the grip of a history that roots humanity's origins in Mesopotamia some six thousand years ago. We now know that our deep past is an African past, because that is where our species evolved. Around fifty thousand years ago, small groups of fully modern humans left that continent and subsequently colonized the world in a breathtaking expansion that began in South Asia and Australia, extended to East Asia and Europe, and finally reached the Americas at the end of the last ice age. Out-of-Africa populations soared as humans escaped African pathogens and learned how to exploit new ecological niches. Those who went north gradually lost their darker skin, and other groups experienced equally minor morphological changes as they adapted to new environments. In the last several hundred years, some of us were dragged violently off the ancestral continent. But we are all African. ${ }^{103}$ That is where any genealogical tree will eventually take you. Every history curriculum in secondary schools and colleges that tacitly accepts a Near Eastern origin around six thousand years ago contains the unintended echo of the Judeo-Christian mythology of the special creation of man in the Garden of Eden. The full incorporation of humanity's African past in the grand historical narrative, in other words, is not just part of an idiosyncratic attempt to colonize the discipline of paleoanthropology. It is an intellectual and moral imperative.

${ }^{102}$ In order, see Robin Dunbar, Grooming, Gossip, and the Evolution of Language (Cambridge, Mass., 1996); Elliot Sober and David Sloan Wilson, Unto Others: The Evolution and Psychology of Unselfish Behavior (Cambridge, Mass., 1998); Christopher Boehm, Hierarchy in the Forest: The Evolution of Egalitarian Behavior (Cambridge, 1999); Sarah Blaffer Hrdy, Mother Nature: A History of Mothers, Infants, and Natural Selection (New York, 1999); and David Sloan Wilson, Darwin's Cathedral: Evolution, Religion, and the Nature of Society (Chicago, 2002).

${ }^{103}$ For this formula, see Reader, Africa.

Dan Smail researches and writes about medieval European history when he is not otherwise engaged in pursuing the possibilities of deep history. He has published several books and articles related to the social and cultural history of Marseille in the later Middle Ages. After completing his Ph.D. at the University of Michigan in 1994, he taught for ten years at Fordham University before moving, in January of 2006, to the Department of History at Harvard University. In addition to several projects in medieval history, he is completing the manuscript for a book tentatively entitled "Outlines for a Deep History of Humankind" and hopes to get a chance to write the deep history itself. 
Copyright of American Historical Review is the property of American Historical Association and its content may not be copied or emailed to multiple sites or posted to a listserv without the copyright holder's express written permission. However, users may print, download, or email articles for individual use. 